\title{
PENGEMBANGAN EKOWISATA BAHARI DI KECAMATAN PADANG CERMIN KABUPATEN PESAWARAN PROVINSI LAMPUNG (Marine Ecotourism Development in Padang Cermin, Pesawaran District, Lampung Province)
}

\author{
Muhammad Altab, Lies Rahayu Wijayanti Faida dan Chafid Fandeli \\ Program Studi Pascasarjana Ilmu Kehutanan, Universitas Gadjah Mada, \\ Bulaksumur Yogyakarta 55281.
}

*Penulis korespondensi. Tel: 085266180361. Email: altab_muhammad@yahoo.com.

\author{
Diterima: 16 Maret 2017
}

Disetujui: 15 Maret 2018

\begin{abstract}
Abstrak
Kajian pengembangan ekowisata bahari di Kecamatan Padang Cermin Kabupaten Pesawaran Provinsi Lampung telah dilakukan. Tujuan penelitian adalah untuk mengidentifikasi potensi atraksi wisata bahari yang ada, mengetahui persepsi wisatawan dan partisipasi masyarakat terhadap pengembangan ekowisata dari aspek sosial, ekonomi dan lingkungan, serta merumuskan strategi pengembangan ekowisata bahari yang sesuai dengan potensi atraksi wisata bahari dan potensi pasar yang dimilikinya. Sebagai responden dipilih sejumlah 100 orang wisatawan dan 100 orang masyarakat dipilih dari empat objek yaitu Pantai Mutun, Pantai Klara, Pantai Sari Ringgung dan Pulau Pahawang. Data dikumpulkan dengan melakukan wawancara dan observasi. Analisis potensi dan daya tarik wisata alam menggunakan pedoman Analisis Daerah Operasi-Objek dan Daya tarik Wisata Alam (ADO-ODTWA). Analisis SWOT digunakan untuk menentukan strategi pengembangan ekowisata dan AHP untuk menentukan tingkat priorotas strategi pengembangan ekowisata. Hasil penelitian adalah bahwa Kecamatan Padang Cermin Kabupaten Pesawaran memiliki potensi yang sangat sesuai untuk pengembangan ekowisata bahari dan disetujui masyarakat setempat. Persepsi wisatawan terhadap potensi objek ekowisata bahari dari aspek ketersediaan fasilitas dan sarana prasarana penunjang masih rendah. Beberapa prioritas strategi pengembangan ekowisata bahari telah dibahas pada aspek ekologi sosial, dan ekonomi.
\end{abstract}

Kata kunci: strategi pengembangan, ekowisata bahari, persepsi wisatawan, partisipasi masyarakat.

\begin{abstract}
Study of marine ecotourism development in Padang Cermin, Pesawaran District, Lampung Province has been carried out. The research objectives are to identify the potential of existing marine tourism attractions, finding out the perceptions of tourists and public participation in the development of ecotourism from social, economic and environmental aspects, and to formulate a marine ecotourism development strategy that is in accordance with the potency of marine tourism attractions and its market potential. As respondents, 100 tourists were selected and 100 people were selected from four objects, namely Mutun Beach, Klara Beach, Sari Rutut Beach and Pahawang Island. Data collecting was conducted using interview and observation. Data was collected by interview and observation. Analysis potential and attractive ecotourism used the orientation of operation area analysis object and motivation ecotourism. SWOT analysis was used to determine development strategy of ecotourism and AHP is used to determine the priority level of ecotourism development strategy. The result showed that Padang Cermin District, Pesawaran Regency, has a very suitable potential for the development of marine ecotourism and has been approved by the local community. The perception of tourists about the potential objects of marine ecotourism from the aspect of the availability of supporting facilities and infrastructure is still low. Several priority strategies for developing marine ecotourism have been discussed in the aspects of social and economic ecology.
\end{abstract}

Keywords: development strategies, marine ecotourism, perception of tourists, public participation.

\section{PENDAHULUAN}

Pergeseran konsep kepariwisataan dunia kepada pariwisata minat khusus atau yang salah satunya dikenal dengan ekowisata bila diterapkan di alam, merupakan sebuah peluang besar bagi Indonesia. Ekowisata sebagai suatu bentuk perjalanan wisata yang bertanggung jawab ke kawasan alami yang dilakukan dengan tujuan mengkonservasi lingkungan dan melestarikan kehidupan dan kesejahteraan penduduk setempat, memperlihatkan kesatuan konsep yang terintegratif secara konseptual tentang keseimbangan antara menikmati keindahan alam dan upaya mempertahankannya (Fandeli, 2002).

Pemanfaatan potensi wilayah pesisir untuk pengembangan ekowisata bahari dapat dilakukan mengingat pada garis pantai banyak mengandung beragam ekosistem yang saling berkaitan erat (Fandeli dan Nurdin, 2005). Hutan mangrove, 
pantai berpasir, padang lamun serta terumbu karang sangat cocok dengan konsep ekowisata atau wisata yang berwawasan lingkungan. Konsep tersebut mengutamakan aspek konservasi alam, aspek pemberdayaan sosial budaya ekonomi masyarakat lokal serta aspek pembelajaran dan pendidikan. Pengembangan ekowisata harus dilakukan dengan seminimal mungkin memberikan dampak terhadap ekosistem yang ada.

Usaha pengembangan pariwisata yang berorientasi pada masyarakat lokal masih minim. Hal ini dikarenakan masyarakat tidak memiliki kemampuan secara finansial dan keahlian yang berkualitas untuk mengelolanya atau terlibat secara langsung dalam kegiatan ekowisata. Potensi ekowisata yang ada masih belum semuanya teridentifikasi. Objek yang ada juga masih belum dikelola secara optimal. Selain itu, kurangnya peran serta dari stakeholders terkait juga menjadi masalah yang harus diselesaikan. Beberapa penelitian telah dilaporkan membahas pengembangan ekowista dalam kaitannya dengan peran masyarakat, antara lain adalah Nurhasan (2002) yang meneliti pengembangan obyek wisata Cangkung, Irianto (2011) tentang pengembangan wisata dan dampaknya di Gili Trawangan, serta oleh Mansuri (2014) terkait wisata di gunung Nglanggeran. Penelitian serupa dilakukan di kawasan Pulau Kaledupa, Kabupaten Wakatobi, Provinsi Sulawesi Tenggara (Salim dan Purbani, 2015) dan Kampung Tanjung Batu, Kecamatan Pulau Derawan, Kabupaten Berau (Mukhlisi, 2017). Dengan melihat potensi wisata alam yang ada pada wilayah Kecamatan Padang Cermin Kabupaten Pesawaran maka perlu dikaji secara lebih mendalam soal pengembangan sebagai ekowisata bahari di sana. Diketahui terdapat banyak pantai alami yang indah, antara lain yang berpotensi adalah Pantai Mutun, Pantai Klara, Pantai Sari Ringgung dan Pulau Pahawang.

Tujuan penelitian ini adalah untuk: (1) Mengidentifikasi potensi atraksi wisata bahari yang terdapat di Kecamatan Padang Cermin. (2) Menganalisis persepsi wisatawan dan partisipasi masyarakat terhadap pengembangan ekowisata bahari dari aspek sosial, ekonomi dan lingkungan yang ada di Kecamatan Padang Cermin. (3) Merumuskan strategi pengembangan ekowisata bahari yang sesuai dengan potensi atraksi wisata bahari dan potensi pasar yang dimiliki Kecamatan Padang Cermin.

\section{METODE PENELITIAN}

\section{Waktu dan Lokasi}

Penelitian ini dilakukan pada bulan JanuariMaret 2016. Penelitian ini dilakukan pada kawasan pantai di wilayah pesisir Kecamatan Padang Cermin Kabupaten Pesawaran. Objek daya tarik ekowisata berupa pantai yang dijadikan sebagai lokasi dalam penelitian ini adalah Pantai Mutun, Pantai Sari Ringgung, Pantai Klara dan Pulau Pahawang.

\section{Bahan dan Alat}

Bahan dan alat yang digunakan dalam penelitian ini antara lain peta-peta Kabupaten Pesawaran, GPS (Global Positioning System) receiver, kamera, tally sheet, alat tulis, kuisioner wawancara, digital voice recorder, komputer dan perangkat lunak pendukungnya.

\section{Prosedur \\ Metode pengumpulan data}

Pengumpulan data dilakukan dengan cara studi literatur, observasi lapangan, kuesioner dan wawancara mendalam yang dilakukan terhadap para stakeholder, terdiri dari Dinas Pariwisata dan Ekonomi Kreatif Kabupaten Pesawaran, pelaku industri pariwisata, wisatawan, masyarakat di sekitar objek ekowisata; dan Kelompok Sadar Wisata (POKDARWIS).

\section{Analisis data}

Data terkumpul selanjutnya dilakukan dengan metode analisis potensi produk wisata, analisis swot dan analytical hierarchy process. Analisis potensi produk wisata (Atraksi, Amenitas dan Aksesibilitas) menggunakan sistem nilai skoring dan pembobotan berdasarkan pedoman analisis ADO-ODTWA yang ditetapkan oleh Direktorat Jenderal PHKA tahun 2003. Analisis SWOT membandingkan faktor internal (kekuatan dan kelemahan) dan eksternal (peluang dan ancaman) terhadap pengembangan ekowisata bahari di Kecamatan Padang Cermin Kabupaten Pesawaran (Rangkuti, 2000). Analytical Hierarchy Process Method merupakan dasar untuk membuat suatu keputusan, yang didesain dan dilakukan secara rasional dengan membuat pilihan yang terbaik terhadap beberapa altenatif yang dievaluasi dengan multikriteria (Saaty, 1993). AHP ini selanjutnya diteruskan dengan pengolahan melalui program Expet Choice 11.

\section{HASIL DAN PEMBAHASAN}

\section{Penilaian Produk Ekowisata}

Penilaian terhadap potensi produk ekowisata Kecamatan Padang Cermin Kabupaten Pesawaran mengacu pada pedoman Analisis Daerah Operasi Objek dan Daya Tarik Wisata Alam (ADOODTWA) yang dikeluarkan oleh Direktorat Jenderal PHKA tahun 2003. 
Tabel 1. Klasifikasi kriteria penilaian produk ekowisata Kecamatan Padang Cermin Kabupaten Pesawaran.

\begin{tabular}{|c|c|c|c|c|c|c|}
\hline \multirow[t]{2}{*}{ No } & \multirow[t]{2}{*}{ Kriteria penilaian } & \multicolumn{2}{|c|}{ Nilai } & \multirow[t]{2}{*}{ Interval } & \multirow[t]{2}{*}{ Nilai potensi } & \multirow[t]{2}{*}{ Klasifikasi } \\
\hline & & Min & Max & & & \\
\hline \multirow[t]{5}{*}{1.} & $\begin{array}{l}\text { Atraksi objek daya tarik } \\
\text { wisata pantai : }\end{array}$ & & & & & \\
\hline & a. Pantai Mutun & & & & 810 & Sangat sesuai \\
\hline & b. Pantai Sari Ringgung & 300 & 900 & 200 & 870 & Sangat sesuai \\
\hline & c. Pantai Klara & & & & 870 & Sangat sesuai \\
\hline & d. Pulau Pahawang & & & & 870 & Sangat sesuai \\
\hline \multirow[t]{3}{*}{2.} & Amenitas & & & & & \\
\hline & a. Sarana dan prasarana & 60 & 180 & 40 & 150 & Sangat sesuai \\
\hline & b. Akomodasi & 30 & 90 & 20 & 30 & Tidak Sesuai \\
\hline 3. & Aksesibilitas & 250 & 750 & 166 & 500 & sesuai \\
\hline
\end{tabular}

Sumber: data pribadi 2016

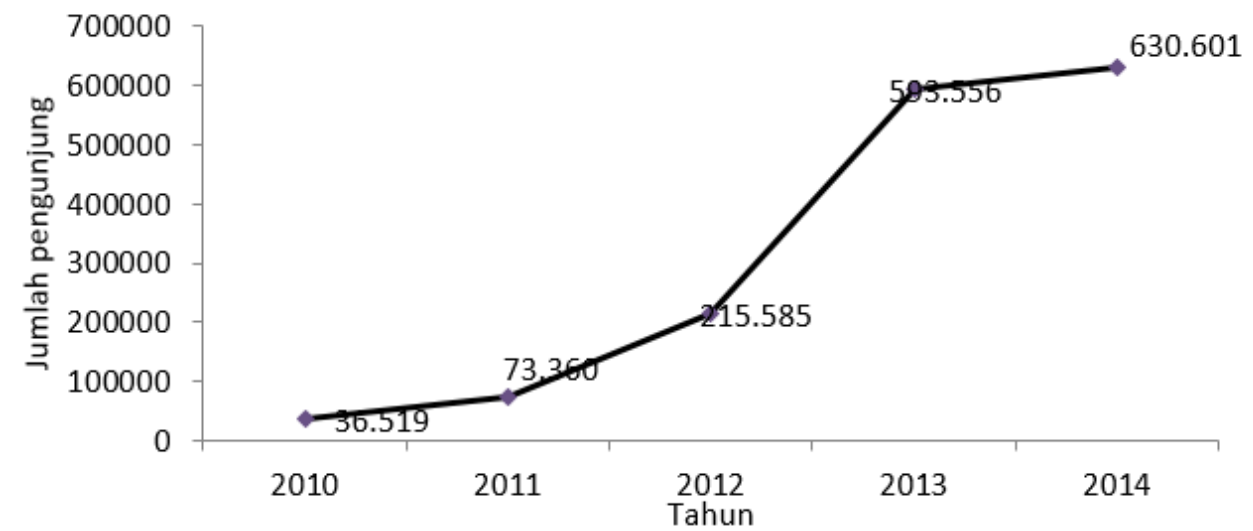

Gambar 1. Jumlah kunjungan wisatawan di Kabupaten Pesawaran periode tahun 2010-2014.

Berdasarkan penelitian terhadap potensi produk ekowisata Kecamatan Padang Cermin Kabupaten Pesawaran memiliki klasifikasi sangat sesuai dari kriteria atraksi menurut pedoman Analisis Daerah Operasi Objek dan Daya Tarik Wisata Alam (ADO-ODTWA) yang dikeluarkan oleh Direktorat Jenderal PHKA tahun 2003. Atraksi ini dapat menjadi produk unggulan sebagai objek daya tarik utama guna pengembangan ekowisata bahari yang ada di Kecamatan Padang Cermin Kabupaten Pesawaran. Penilaian terhadap Atraksi ini difokuskan kepada keunikan dan keindahan, keselamatan dan keamanan pantai, variasi kegiatan, kebersihan serta kenyamanan.

Hasil penilaian terhadap amenitas seperti sarana dan prasarana menunjukkan bahwa Kawasan ekowsiata Kecamatan Padang Cermin memiliki fasilitas umum yang sangat sesuai menurut klasifikasi ADO-ODTWA. Fasilitas umum tersebut berupa air bersih (PDAM), layanan listrik (PLN), serta fasilitas layanan telekomunikasi berupa sambungan telepon seluler ataupun akses internet. Untuk aspek penunjang amenitas berupa fasilitas pelayanan kesehatan sudah terdapat puskesmas serla klinik-klinik kesehatan. Fasilitas keamanan terdapat kantor polsek dan koramil serta terdapat pula markas TNI AL Lampung. Kriteria penilaian terhadap akomodasi masuk dalam klasifikasi tidak sesuai. Hal ini disebabkan karena masih kurangnya jumlah ketersediaan penginapan yang ada di kawasan ekowisata bahari yang ada di Kecamatan Padang Cermin.

Aksesibilitas menuju ke kawasan ekowisata di Kecamatan Padang Cermin dapat dikatakan memiliki keterjangkauan yang tinggi, karena berada dalam satu jalur utama jalan pesisir Kabupaten Pesawaran. Akan tetapi, ketersediaan alat transportasi umum yang melayani perjalanan dari Kota Bandar Lampung ataupun Gedongtaan masih sangat terbatas jumlah dan frekuensinya

\section{Potensi Pasar}

Pariwisata pada saat ini menjadi harapan bagi banyak daerah sebagai sektor yang dapat diandalkan untuk mendukung pertumbuhan ekonomi dan pembangunan. Perkembangan kepariwisataan alam atau ekowisata di suatu daerah dapat dilihat berdasarkan jumlah wisatawan yang berkunjung ke kawasan wisata. Berikut data perkembangan jumlah pengunjung pada 5 (lima) tahun terakhir (2010-2014) di Kabupaten Pesawaran.

\section{Persepsi Wisatawan}

Pada penelitian ini dilakukan wawancara dan penyebaran kuesioner terhadap 100 orang wisatawan yang tersebar di 4 (empat) lokasi penelitian yaitu Pantai Mutun, Pantai Sari 
Ringgung, Pantai Klara dan Pulau Pahawang. Menurut wisatawan yang berkunjung ke kawasan objek ekowisata bahari yang ada di Kecamatan Padang Cermin sebesar $76 \%$ wisatawan berpendapat bahwa fasilitas pada objek ekowisata yang ada masih belum lengkap, sedangkan 66\% wisatawan juga berpendapat bahwa fasilitas yang ada pada kawasan objek ekowisata masih belum dalam keadaan baik. Dari hasil tersebut maka perlu adanya upaya yang harus dilakukan oleh pengelola untuk segera melakukan perbaikan atau pembangunan fasilitas untuk menunjang kelancaran dalam kegiatan ekowisata bahari.

\section{Partisipasi Masyarakat}

Peranserta atau partisipasi dapat didefinisikan sebagai keterlibatan mental atau pikiran dan emosi atau perasaan seseorang di dalam situasi kelompok yang mendorongnya untuk memberikan sumbangan kepada kelompok dalam usaha mencapai tujuan serta turut bertanggung jawab terhadap usaha yang bersangkutan (Sastropoetro, 1998). Masyarakat Desa Sidodadi, Desa Sukajaya Lempasing, Desa Gebang dan Pulau Pahawang sangat berperan dalam pengembangan ekowisata bahari yang ada di Kecamatan Padang Cermin Kabupaten Pesawaran. Partisipasi yang dilakukan oleh masyarakat dalam kegiatan ekowisata sangat berdampak pada perkembangan ekowisata yang ada disana.

Pada awal pembukaannya sebagai tempat wisata peran masyarakat sangatlah besar. Dimulai dari pembangunan akses jalan menuju pantai, pembuatan MCK serta masyarakat sebagai pekerja ditempat objek wisata. Partisipasi sejenis ini tergolong dalam karakter partisipasi konsulatif, menurut Pretty (1995) partisipasi konsulatif yaitu dimana masyarakat berpartisipasi dengan cara berkonsultasi, melakukan dengar pendapat, sedangkan orang luar mendengarkan, menganalisis masalah dan pemecahannya. Masyarakat berkonsultasi dan melakukan dengar pendapat dalam bentuk memberikan usulan dengan pihak luar, dalam hal ini adalah pengelola objek wisata (pemilik objek wisata). Bentuk-bentuk lain dari pertisipasi masyarakat dalam usaha ekowisata adalah dengan menjadi penjual makanan dan minuman, menyewakan perahu motor, menjadi guide dan pengelola homestay.

\section{Analisis SWOT}

Berdasarkan analisa SWOT, maka diketahui faktor internal (kekuatan dan kelemahan) dan eksternal (peluang dan ancaman) dalam pengembangan ekowisata Kecamatan Padang Cermin Kabupaten Pesawaran. Faktor-faktor tersebut yaitu:
1. Kekuatan : Potensi sumber daya alam untuk kegiatan ekowisata bahari masih sangat besar, banyak terdapat pulau-pulau kecil di sekitar daerah wisata yang dapat dijadikan daya tarik untuk menikmati keindahan alam, dukungan pemerintah, lokasi objek wisata sangat mudah untuk dijangkau, kondisi lingkungan yang aman dan nyaman, masyarakat sekitar lokasi objek wisata sangat antusias dan menerima dengan baik datangnya wisatawan, tersedianya sumber daya manusia yang berpotensi menjadi tenaga kerja.

2. Kelemahan : Promosi wisata yang sangat terbatas, belum adanya koordinasi antara pemerintah daerah dan pengusaha ekowisata bahari, masih kurangnya pendekatan yang dilakukan oleh pemerintah daerah terhadap masyarakat di daerah ekowisata bahari, masih terbatasnya pusat oleh-oleh dan toko souvenir, masih terbatasnya sarana dan prasarana pendukung pelaksanaan pembangunan ekowisata bahari, lemahnya kesadaran wisatawan untuk tetap menjaga kelestarian alam, belum adanya peraturan daerah dibidang ekowisata bahari, belum adanya Rencana Induk Pengelolaan oleh pemerintah daerah. Ditinjau dari faktor eksternal yang mempengaruhi pengembangan ekowisata.

3. Peluang : Peningkatan minat ekowisata, dukungan Pemariantah terhadap pengembangan ekowisata bahari, adanya investor yang ingin berinvestasi.

4. Ancaman : Ancaman kerusakan lingkungan dari adanya kegiatan ekowisata, degradasi lahan guna memenuhi tuntutan perluasan lokasi ekowisata, korban jiwa akibat lemahnya pengawasan serta kesadaran wisatawan akan bahayanya kegiatan ekowisata bahari, konflik antar masyarakat ataupun antar pengelola objek wisata.

Faktor internal dan eksternal tersebut kemudian dirumuskan melalui matriks SWOT. Matriks ini menghasilkan empat strategi pengembangan ekowisata di Kecamatan Padang Cermin Kabupaten Pesawara yaitu; strategi SO, WO, ST dan WT.

Berdasarkan analisis SWOT diperoleh beberapa isu strategis pengembangan ekowisata bahari yang dapat dilakukan. Isu strategis tersebut tetap harus mengacu pada prinsip-prinsip ekowisata yaitu berbasis pada alam, konservasi, mengandung unsur pendidikan lingkungan, member manfaat bagi masyarakat lokal dan adanya kepuasan wisatawan. Isu-isu strategis tersebut yaitu pemanfaatan potensi sumber daya alam, pengendalian terhadap kerusakan lingkungan, 
perbaikan kondisi ekosistem, dukungan pemerintah daerah, pengembangan kualitas SDM, penguatan komunikasi antar pihak, peningkatan promosi, peningkatan peluang usaha, dan pengembangan bantuan modal.

\section{Analytical Hirarchy Process (AHP)}

Alternatif strategi pengembangan ekowisata di Kecamatan Padang Cermin Kabupaten Pesawaran tersebut selanjutnya ditampilkan dalam bentuk hirarki (Gambar 2). Pilihan strategi yang telah ada, kemudian akan dilakukan analisis oleh para pihak untuk menentukan prioritas strategi pengembangan.

Berdasarkan hasil analisis dengan proses hirarki terhadap pihak-pihak yang berkepentingan, diperoleh bahwa aspek ekologi masih menjadi tujuan utama pengembangan ekowisata di Kecamatan Padang Cermin dibandingkan dengan aspek sosial dan ekonomi. Dengan kata lain aspek ekologi menjadi sangat penting karena hal tersebut menjadi objek daya tarik utama untuk dapat menarik minat wisatawan untuk datang dan mengunjungi objek-objek ekowisata yang ada disana.

Kualitas lingkungan dalam arti luas meliputi sumber daya alam dan buatan, memiliki hubungan yang komplek dengan aktivitas ekowisata. Hubungan tersebut melibatkan beragam aktivitas yang dapat menghasilkan dampak-dampak positif atau negatif. Dampak positifnya adalah lahirnya manfaat berupa perlindungan dan konservasi lingkungan, lahirnya kesadaran tentang nilai-nilai lingkungan. Sedangkan dampak negatifnya adalah aktivitas-aktivitas selama pembangunan infrastruktur jalan, jembatan, dermaga dan sebagainya, hingga sarana ekowisata seperti hotel/penginapan, restoran, resort, pantai dan aktivitas-aktivitas ekowisata lain yang dapat mencemari lingkungan.

Menurut Damanik dan Teguh (2012), pariwisata akan berkelanjutan jika di dalam pengelolaannya dapat diseimbangan capaian nilai ekologi, sosial dan ekonomi. Langkah-langkahnya yaitu melindungi dan meningkatkan daya tarik wisata alam dan buatan, menggunakan setiap sumberdaya yang sesuai dan menghasilkan kontribusi nyata bagi kesejahteraan masyarakat yang ada di sekitar objek wisata, menjamin kesesuaian promosi dengan fakta destinasi dan mendorong pertambahan kunjungan ulang.

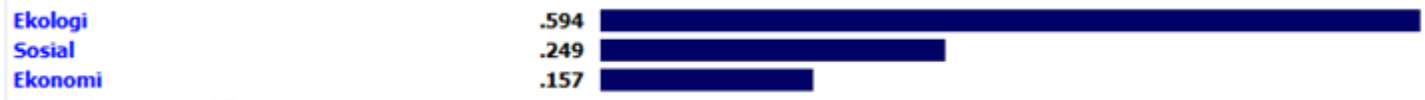

Gambar 2. Prioritas aspek pengembangan ekowisata Kecamatan Padang Cermin.

Tabel 2. Matriks SWOT strategi pengembangan ekowisata di Kecamatan Padang Cermin Kabupaten Pesawaran.

\begin{tabular}{|c|c|c|}
\hline & Kekuatan (S) & Kelemahan (W) \\
\hline $\begin{array}{l}\text { Peluang } \\
\text { (O) }\end{array}$ & $\begin{array}{l}\text { StrategiS-O } \\
\text { 1. Pemanfaatan potensi sumber daya alam, } \\
\text { keanekaragaman hayati laut dengan } \\
\text { menarik investasi dalam pengembangan } \\
\text { ekowisata bahari. } \\
\text { 2. Pengembangan bantuan modal usaha } \\
\text { 3. Meningkatkan peran serta dan kerjasama } \\
\text { pemda dengan masyarakat dalam } \\
\text { kegiatan ekowisata bahari. } \\
\text { 4. Meningkatkan pemberdayaan } \\
\text { masyarakat dan partisipasi semua } \\
\text { stakeholder yang didukung oleh regulasi } \\
\text { atau kebijakan pemda yang sesuai } \\
\text { dengan tujuan pembangunan daerah. }\end{array}$ & $\begin{array}{l}\text { Strategi W-O } \\
\text { 1. Meningkatkan peran serta dan kerjasama } \\
\text { masyarakat, pemda dan semua pihak terkait } \\
\text { dalam meningkatkan promosi ekowisata bahari } \\
\text { 2. Penguatan komunikasi para pihak dengan } \\
\text { membuat unit-unit atau lembaga pengelolaan } \\
\text { ekowisata bahari bersama masyarakat, LSM dan } \\
\text { pihak swasta. } \\
\text { 3. Menyusun peraturan daerah terkait ekowisata } \\
\text { 4. Sosialisai kepada semua pihak yang terkait } \\
\text { dalam kegiatan ekowisata bahari tentang penting } \\
\text { kelestarian lingkungan }\end{array}$ \\
\hline $\begin{array}{c}\text { Ancaman } \\
\text { (T) }\end{array}$ & $\begin{array}{l}\text { Strategi S-T } \\
\text { 1. Mendorong aktivitas ekowisata bahari } \\
\text { yang tidak merusak lingkungan } \\
\text { 2. Sosialisasi tentang kegiatan konservasi, } \\
\text { seperti pelestarian lingkungan, terumbu } \\
\text { karang dan hutan mangrove kepada } \\
\text { masyarakat lokal } \\
\text { 3. Meningkatkan pengawasan tentang } \\
\text { keselamatn wisatawan } \\
\text { 4. Meningkatkan keterampilan serta } \\
\text { kempampuan masyarakat yang terkait } \\
\text { dengan kegiatan ekowisata bahari. }\end{array}$ & $\begin{array}{l}\text { Strategi W-T } \\
\text { 1. Penyusunan "masterplan" atau rencana induk } \\
\text { pengembangan ekowisata bahari } \\
\text { 2. Menyusun SOP keselamatan berwisata bagi } \\
\text { pengunjung } \\
\text { 3. Membentuk badan pengelola ekowisata bahari } \\
\text { sebagai penghubung antara pemda, masyarakat } \\
\text { dan pengusaha ekowisata bahari. } \\
\text { 4. Membangun sarana dan prasarana penunjang } \\
\text { kegiatan ekowisata bahari } \\
\text { 5. Membangun akses, transportasi dan komunikasi } \\
\text { sebagai penunjang kegiatan ekowisata bahari }\end{array}$ \\
\hline
\end{tabular}



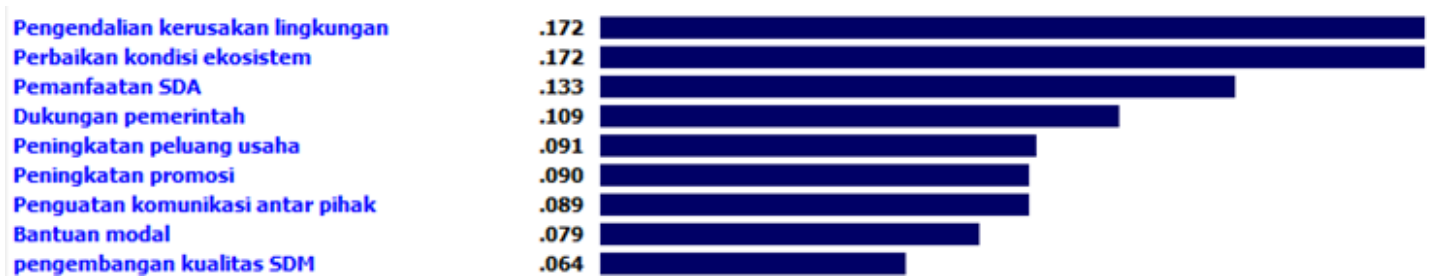

Gambar 3. Prioritas pengembangan ekowisata Kecamatan Padang Cermin.

Seperti disajikan pada Gambar 3, maka pengendalian kerusakan lingkungan menjadi prioritas pertama dalam upaya pengembangan ekowisata bahari di Kecamatan Padang Cermin. Ekowisata merupakan suatu konsep pariwisata yang menCerminkan wawasan lingkungan dan mengikuti kaidah-kaidah keseimbangan dan kelestarian lingkungan. Dalam pengembangan ekowisata, pendidikan serta konservasi menjadi sangat penting guna menjaga kelestarian lingkungan.

Pilihan prioritas kedua dalam upaya pengembangan ekowisata di Kecamatan Padang Cermin yaitu perbaikan kondisi ekosistem. Dengan semakin meningkatnya penduduk dan pesatnya kegiatan pembangunan serta kegiatan ekowisata di wilayah pesisir, maka tekanan ekologis terhadap ekosistem dan sumber daya pesisir dan laut itu semakin meningkat.

Pemanfaatan sumber daya alam menjadi prioritas ketiga dalam upaya pengembangan ekowisata bahari di Kecamatan Padang Cermin. Pemanfaatan sumber daya alam secara bijak dengan mengacu pada kaidah-kaidah konservasi sangat perlu dilakukan. Selain itu kepedulian terhadap lingkungan sangat penting diterapkan sebagai upaya meminimalisir dampak dari pemanfaatan sumber daya alam untuk kegiatan ekowisata bahari.

Dukungan pemerintah menjadi prioritas keempat. Pemerintah daerah dapat berperan dalam memberikan aturan, pengawasan dan pendampingan serta memfasilitasi segala bentuk kegiatan yang bertujuan untuk mendukung pengembangan ekowisata bahari yang ada di wilayahnya. Dukungan pemerintah daerah dalam pengembangan ekowisata bahari ini tentunya tidak hanya pada pengembangan objek wisata saja, namun juga pada komponen lain sebagai penunjang kegiatan ekowisata seperti perbaikan dan penambahan infrastruktur, fasilitas-fasilitas umum dan dalam kelancaran administrasi serta keberadaan kelembagaan.

Prioritas kelima dalam upaya pengembangan ekowisata di Kecamatan Padang Cermin yaitu peningkatan peluang usaha bagi masyarakat. Karena dengan adanya kegiatan ekowisata ini diharapkan dapat berdampak positif bagi masyarakat lokal. Pendampingan dan pemberian pelatihan dimungkinkan untuk dilakukan oleh pemerintah daerah kepada masyarakat lokal dengan tujuan agar masyarakat lebih dapat memanfaatkan peluang usaha yang datang dari kegiatan ekowisata bahari.

Promosi menjadi prioritas keenam dalam upaya pengembangan ekowisata bahari di Kecamatan Padang Cermin Promosi merupakan bagian manajemen terpenting dalam memasarkan ekowisata. Masyarakat secara luas diangkat kesadarannya agar tertarik dan ingin menyaksikan fenomena yang ada secara spesifik dan nyata, tanpa upaya melebih-lebihkan dari keadaan yang sesungguhnya. Promosi ditujukan untuk mengenalkan produk atau fenomena yang ada, sehingga semakin banyak orang yang mendapatkan informasi mengenai objek wisata yang ingin dipasarkan.

Penguatan komunikasi antar pihak (kelembagaan) menjadi prioritas ketujuh. Saat ini komunikasi berbagai pihak yang terlibat dalam sektor pariwisata yang ada di Kabupaten Pesawaran masih sangat lemah. Terdapat perbedaan cara pandang dalam pengelolaan maupun pengembangan antara pemerintah daerah, pengusaha wisata serta individu ataupun kelompok masyarakat. Lemahnya komunikasi ini berdampak pada tidak sejalannya pandangan serta tujuan pihak-pihak yang terlibat dalam kegiatan ekowisata yang ada di Kabupaten Peswaran.

Prioritas kedelapan dalam upaya pengembangan ekowisata di Kecamatan Padang Cermin yaitu bantuan modal. Saat ini bisnis di sektor pariwisata merupakan bisnis yang sangat menguntungkan. Sayangnya bisnis ini hanya dinikmati oleh kalangan swasta dan investor yang menanamkan modalnya dibidang pariwisata. Seharusnya masyarakat lokal dapat menangkap peluang usaha dari adanya kegiatan pariwisata di tempatnya.

Pengembangan kualitas sumber daya manusia menjadi prioritas pengembangan kesembilan. Sumber daya manusia merupakan elemen penting dalam pengelolaan suatu objek ekowisata dalam jangka waktu pendek maupun dalam jangka waktu yang panjang. Tersedianya sumber daya manusia yang mumpuni juga merupakan faktor penetu 
keberhasilan dalam upaya pengembangan ekowisata bahari yang ada di Kecamatan Padang Cermin. Untuk itu perlu adanya peningkatan kualitas melalui pendidikan, pelatihan atau pembinaan.

\section{KESIMPULAN}

Kecamatan Padang Cermin memiliki potensi objek dan daya tarik ekowisata bahari berupa pantai dan pulau-pulau kecil, untuk berbagai variasi kegiatan. Hal ini terlihat dari masing-masing objek dengan kondisi pantai dan perairan yang sangat baik untuk aktivitas tersebut.

Persepsi wisatawan terhadap potensi objek ekowisata bahari dari aspek ketersediaan fasilitas dan sarana prasarana penunjang masih rendah jika dilihat dari kelengkapan dan kondisinya. Kondisi lingkungan pada kawasan objek ekowisata bahari di Kecamatan Padang Cermin sangat memungkinkan untuk dijadikan daya tarik utama dalam pengembangannya bagi wisatawan. Masyarakat sangat setuju apabila daerahnya dikembangkan sebagai objek ekowisata bahari dan merasa sangat senang apabila ada wisatawan yang datang ke daerahnya. Sebagian masyarakat memanfaatkan peluang usaha dari kegiatan ekowisata bahari sehingga mampu memberikan kontribusi pemasukan untuk memenuhi kebutuhan sehari-hari. Selain itu dengan adanya kegiatan ekowisata bahari ini dapat merubah keadaan sosial masyarakat yanag ada di sekitarnya.

Berdasarkan hasil analisis yang dilakukan, diperoleh prioritas strategi pengembangan ekowisata bahari yang ada di Kecamatan Padang Cermin sebagai berikut; (a) Pada aspek ekologi prioritas pengembangan terpusat pada Pengendalian terhadap kerusakan lingkungan, perbaikan kondisi ekosistem dan pemanfaatan potensi sumber daya alam, (b) Pada aspek sosial prioritas pengembangan terpusat pada dukungan dari pemerintah daerah, penguatan komunikasi antar pihak dan pengembangan kualitas SDM, (c) Pada aspek ekonomi prioritas pengembangan terfokus pada peningkatan promosi, peningkatan, peningkatan bantuan modal dan peningkatan peluang usaha.

\section{DAFTAR PUSTAKA}

Damanik, J., dan Teguh, F., 2012. Manajemen Destinasi Pariwisata - Sebuah Pengantar Ringkas. Kepel Press, Yogyakarta.
Direktorat Jenderal Perlindungan Hutan dan Konservasi Alam. 2003. Analisis Daerah Operasi Objek dan Daya Tarik Wisata Alam ADO-ODTWA). Departemen Kehutanan. Bogor.

Fandeli, C., 2002. Perencanaan Kepariwisataan Alam.Gadjah Mada University Press. Yogyakarta

Fandeli, C., dan Nurdin, M., 2005. Pengembangan Ekowisata berbasis Konservasi di Taman Nasional. Fakultas Kehutanan dan Pusat Studi Pariwisata. Universitas Gadjah Mada. Yogyakarta

Irianto, 2011. Dampak Parwisata Terhadap Kehidupan Sosial dan Ekonomi Masyarakat di Gili Trawangan Kecamatan Pemenang Kabupaten Lombok Utara. Jurnal Bisnis \& Kewirausahaan, 7:7-16.

Mansuri, N.W., 2014. Studi Pengembangan Objek Daya Tarik Kawasan Ekowisata Gunung Api Purba Ngelanggeran, Kabupaten Gunung Kidul, D.I. Yogyakarta. Tesis Pasca Sarjana Fakultas Kehutanan Universitas Gadjah Mada. Yogyakarta.

Mukhlisi, 2017. Potensi Pengembangan Ekowisata Mangrove di Kampung Tanjung Batu, Kecamatan Pulau Derawan, Kabupaten Berau. J. Manusia \& Lingkungan, 24(1):23-30.

Nurhasan, D., 2002. Pengembangan Potensi Objek Wisata Alam dan Budaya Cangkung. Jurnal Nasional Pariwisata, 2(2):53-61.

Pretty, J.N., 1995. Participatory Learning for Sustainable Agriculture. World Development, 23(8):1247-1263.

Rangkuti, F., 2000. Analisis SWOT Teknik Membedah Kasus Bisnis. PT Gramedia Pustaka. Jakarta.

Saaty, T.L., 1993. Pengambilan Keputusan Bagi Para Pemimpin: Proses Hierarki Analitik Untuk Pengembilan Keputusan Dalam Situasi Yang Kompleks (Terjemahan), PT. Pustaka Binaman Pressindo, Jakarta.

Salim, H.L., dan Purbani, D., 2015. Pengembangan Pariwisata Bahari Berbasis Masyarakat di Pulau Kaledupa, Kabupaten Wakatobi, Provinsi Sulawesi Tenggara. J. Manusia \& Lingkungan, 22(3):380-387.

Sastropoetro, S. 1998. Partisipasi, Komunikasi, Persuasi. Penerbit Alumni, Bandung. 